\title{
Aktivitas fisik, stress, dan asupan makanan terhadap tekanan darah pada wanita prediabetes
}

\author{
Rohmah Syahitdah, Choirun Nissa*
}

\section{ABSTRACT}

Backgrounds: Prediabetes and hypertension was being a health issue in the world. Prediabetes and hypertension that occur together will increase the risk of developing Type 2 Diabetes Mellitus (T2DM) and cardiovascular disease. Risk factor of prediabetes and hypertension who can changed is phyisical activity, stress, and nutrition intake.

Objectives: This study aims to determine the association between physical activity and stress with blood pressure in prediabetes woman.

Methods: The study was done at Semarang in April-June 2016. The cross-sectional study design with the 28 subjects predibetes woman aged 35-50 years selected by consecutive-sampling method. The data taken were blood presure, fat, fiber, sodium, pottasium, calsium, magneisum intake, physical activity score, and stress score. Spearman test were used to determine the association between physical activity and stress with blood pressure. Linear regression were used to multivariate analysis Results: Seventy five percent of subjects was hypertensive with mean of blood pressure was 89,25 $\pm 14,64 \mathrm{mmHg}$. The result showed that most subject (64,3\%) were minimally active with mean 2.258,4 $\pm 1.228,8$ MET-minutes/week. Majority, subjects were moderate stress (56,3\%). There were an association between physical activity with diastolic pressure, but not in systolic pressure. There were no association between stress with blood pressure.

Conclusion: Physical activity was only associated with diastolic pressure and stress was not associated with blood pressure.

Keywords: physical activity, stress, prediabetes

\section{ABSTRAK}

Latar Belakang:.Prediabetes dan hipertensi merupakan isu kesehatan yang menjadi perhatian dunia. Seseorang yang mengalami prediabetes dan hipertensi secara bersamaan berisiko lebih tinggi untuk berkembang menjadi Diabetes Mellitus Tipe 2 (DMT2) dan penyakit kardiovaskuler. Salah satu faktor risiko prediabetes dan hipertensi yang dapat diubah adalah aktivitas fisik, tingkat stress, dan asupan.

Tujuan: Penelitian ini bertujuan untuk mengetahui hubungan antara aktivitas fisik dan stress dengan tekanan darah wanita prediabetes usia 35-50 tahun di Semarang.

Metode: Penelitian dilaksanakan di Semarang pada bulan April-Juni 2016. Desain penelitian ini adalah cross-sectional dengan subjek 28 wanita prediabetes usia 35-50 tahun yang dipilih dengan metode consecutive sampling. Data yang diambil adalah tekanan darah, skor aktivitas fisik, skor tingkat stress, asupan lemak, serat, sodium, kalium, kalsium, dan magnesium. Analisis bivariat menggunakan Rank Spearman. Analisis multivariate menggunakan uji regresi linier.

Hasil Penelitian: Mayoritas subjek mengalami hipertensi (75\%) dengan rerata tekanan darah 89,25 $\pm 14,64 \mathrm{mmHg}$. Sebagian besar (64,3\%) subjek dikategorikan aktif minimal dengan rerata aktivitas fisik 2.258,4 $1.228,8$ MET-menit/minggu. Tingkat stress subjek mayoritas adalah sedang (53,6\%) dengan skor antara 4-31. Terdapat hubungan yang bermakna antara aktivitas fisik dengan tekanan darah diastolik, tetapi tidak dengan sistolik. Tidak terdapat hubungan antara stress dengan tekanan darah.

Simpulan: Aktivitas fisik mempunyai hubungan dengan tekanan diastolik saja dan stress tidak memiliki hubungan dengan tekanan darah.

Kata kunci: aktivitas fisik, stress, prediabetes, tekanan darah

\section{PENDAHULUAN}

Prediabetes dan hipertensi merupakan salah satu masalah yang menjadi perhatian dunia. Prediabetes merupakan fase fisiologis dimana kadar glukosa darah lebih tinggi diatas normal tetapi belum sampai pada kriteria diabe tes. Seseorang dikatakan prediabetes apabila mengalami salah satu atau kedua kondisi berikut: glukosa darah puasa terganggu (GDPT dimana
GDP: $100-125 \mathrm{mg} / \mathrm{dL}$ ) dan toleransi glukosa terganggu (TGT dimana GDPP: $140-199 \mathrm{mg} / \mathrm{dL}$ ). ${ }^{1-5}$

Penderita prediabetes lebih berisiko berkembang menjadi Diabetes Mellitus Tipe 2 (DMT2). Progresivitas prediabetes menjadi DMT2 sebesar 6$10 \%$ per tahun. Hipertensi juga disebut-sebut menjadi salah satu faktor risiko terjadinya DMT2. Penderita prediabetes yang disertai hipertensi lebih berisiko untuk berkembang menjadi DMT2 dibanding dengan

Departemen Ilmu Gizi, Fakultas Kedokteran, Universitas Diponegoro. Jl. Prof. Sudarto SH, Tembalang, Semarang, Jawa Tengah 50275, Indonesia

${ }^{*}$ Korespondensi: E-mail: nissaeyong@gmail.com 
prediabetes tanpa hipertensi. Di Indonesia, hipertensi sangat berpengaruh terhadap prediabetes dengan RR $56,5 \%$ yang mengindikasikan bahwa apabila hipertensi tidak terjadi maka prevalensi prediabetes dapat menurun sebesar 56,5\%. Oleh karena itu, pengelolaan hipertensi di Indonesia menjadi salah satu aspek penting dalam pencegahan DMT2. ${ }^{2}$

Prevalensi prediabetes semakin meningkat dari tahun ke tahun. Di Indonesia, prevalensi prediabetes meningkat dari 10,2\% di tahun 2007 menjadi 29,9\% di tahun 2010. Prevalensi pada perempuan lebih besar dibanding pada laki-laki. Prevalensi prediabetes pada perempuan di tahun 2010 adalah 32,7\%, sedangkan prevalensi prediabetes pada laki-laki adalah sebesar $25 \%$.

Prediabetes juga lebih banyak terjadi pada penderita hipertensi dibanding pada non-hipertensi. Terdapat hubungan yang erat antara gula darah dengan tekanan darah. Seseorang dengan gula darah yang tinggi lebih berisiko untuk mengalami hipertensi dibandingkan dengan seseorang yang memiliki gula darah normal. Hiperinsulinemia mungkin menjadi salah satu faktor langsung yang menyebabkan naiknya tekanan darah. Hiperinsulinemia meningkatkan retensi sodium di ginjal dan meningkatkan aktivitas sistem saraf simpatetik (SNS-sympathetic nervous system), dimana aktivitas SNS yang berlebih akan mengakibatkan resistensi insulin yang memicu terjadinya hipertensi. Resistensi insulin juga berpengaruh terhadap menurunnya repson vasodilator dan meningkatnya vasokonstriktor pada jaringan perifer, sehingga mengakibatkan meningkatnya tekanan darah sistolik. ${ }^{6}$ Prevalensi prediabetes pada penderita hipertensi lebih besar $(15,1 \%)$ dibanding pada nonhipertensi $(8,4 \%))^{7,8}$

Hipertensi merupakan suatu keadaan dimana tekanan darah lebih dari normal dalam jangka waktu yang lama. Berdasarkan The Seventh Report of the Joint National Committee on Prevention, Detection, Evaluation, and Treatment of High Blood Pressure (JNC 7) seseorang dikatakan mengalami hipertensi apabila tekanan darahnya diatas 140/90 mmHg. Namun, tidak harus tekanan darah sistolik dan diastolik diatas normal untuk dapat dikatakan hipertensi, cukup salah satu memenuhi kriteria hipertensi maka ia sudah dikatakan menderita hipertensi. Sebagai contoh, seseorang yang mempunyai tekanan darah 140/80 $\mathrm{mmHg}$ sudah dikatakan mengalami hipertensi walaupun tekanan darah diastoliknya normal. ${ }^{9}$

Belum ada kriteria khusus mengenai hipertensi pada penderita diabetes. Namun, karena pada penderita diabetes terjadi peningkatan risiko penyakit kardiovaskuler maka para ilmuwan menyatakan bahwa penderita diabetes yang memiliki tekanan darah $\geq 130 / 80$ mmHg sudah dikatakan hipertensi. ${ }^{10-12}$ Prediabetes lebih sering ditemukan terjadi bersamaan dengan hipertensi dibanding terjadi secara tunggal. Hal tersebut kemungkinan disebabkan karena faktor risiko penyakit hampir sama, seperti misalnya kurangnya aktivitas fisik, obesitas, konsumsi alkohol, merokok, dll. ${ }^{13}$

Banyak faktor yang menyebabkan terjadinya hipertensi pada prediabetes, antara lain adalah meningkatnya usia, adanya riwayat keluarga yang mengalami diabetes, obesitas terutama obesitas sentral, inflamasi dan stress oksidatif, resistensi insulin, kurangnya aktivitas fisik, stress, asupan makan yang tidak baik (tinggi asupan sodium dan lemak, rendah asupan kalsium, serat, kalium, dan magnesium), merokok, konsumsi alkohol, dan hiperlipidemia.. ${ }^{3,}$ 14-18 Diantara faktor tersebut, faktor yang dapat diubah adalah kurangnya aktivitas fisik, stress, dan asupan makan.

Kurangnya aktivitas fisik menyebabkan penurunan efektivitas insulin dan buruknya penggunaan glukosa dan lemak di dalam sel. ${ }^{3}$ Banyak penelitian yang telah menunjukkan bahwa aktivitas fisik yang rendah berhubungan dengan hipertensi dan prediabetes, tetapi penelitian di Indonesia menunjukkan hal yang sebaliknya dimana aktivitas fisik tidak berhubungan dengan prediabetes sehingga bukan merupakan faktor risiko terjadinya prediabetes. ${ }^{2}$ Selain itu, pada era modern dimana kehidupan dipermudah dengan adanya teknologi dan sarana transportasi membuat seseorang lebih cenderung untuk memiliki aktivitas yang rendah.

Selain aktivitas fisik, faktor lain yang dapat diubah adalah stress. Stress terjadi apabila tubuh mendapat tekanan baik dari luar maupun dari dalam diri sendiri yang berpengaruh terhadap kondisi fisiologis. Stress yang terjadi secara terus menerus menyebabkan stimulasi sistem SNS yang akan meningkatkan denyut nadi dan output jantung, serta aktifnya sistem reninangiotensin-aldosteron (RAAS). Meningkatnya SNS juga berperan dalan perkembangan gangguan glukosa dan metabolisme lemak. ${ }^{17}$

Penelitian ini bertujuan untuk mengetahui hubungan antara aktivitas fisik dan stress dengan tekanan darah wanita prediabetes setelah dikontrol asupan lemak, serat, sodium, kalium, kalsium, dan magnesium. Pada penelitian ini subjek yang digunakan adalah wanita prediabetes usia 35-50 tahun. Subjek dipilih wanita karena wanita diabetes lebih berisiko mengalami hipertensi. ${ }^{19}$ Wanita dipilih usia 35-50 tahun karena berdasarkan data riskesdas tahun 2007 dan 2010, prevalensi prediabetes lebih tinggi pada wanita dengan usia tersebut dibandingkan pada usia dibawahnya. ${ }^{7,8}$ Selain itu, penelitian menyebutkan bahwa perempuan lebih rentan terkena stress dibanding laki-laki. ${ }^{20}$ Pemilihan subjek prediabetes ini bertujuan untuk memperlambat progresivitas terjadinya DMT2 di kemudian hari. 


\section{BAHAN DAN METODE}

Penelitian ini dilaksanakan di wilayah kerja Puskesmas Kedungmundu dan perkantoran di Semarang pada bulan April - Juni 2016. Penelitian ini termasuk dalam ruang lingkup keilmuan gizi masyarakat dengan desain cross sectional. Populasi terjangkau yang digunakan adalah wanita prediabetes usia 35-50 tahun di wilayah kerja puskesmas Kedungmundu dan perkantoran di Semarang.menggunakan simpang baku rerata 6,09 dan tingkat ketepatan absolut (d) 2,5 dan tingkat kepercayaan $95 \%$ diperoleh jumlah sampel minimal 23 orang. ${ }^{21}$ Hasil perhitungan tersebut ditambah $10 \%$ untuk mengantisipasi adanya drop-out sehingga jumlah sampel minimal yang dibutuhkan adalah 26 orang. Cara pengambilan sampel adalah dengan consecutive sampling dimana subjek yang ditemui dan memenuhi kriteria dimasukkan sampel jumlah subjek terpenuhi.

Subjek diperoleh melalui dua tahap skrining. Tahap pertama melalui kriteria Indeks Massa Tubuh (IMT) $\geq 23 \mathrm{~kg} / \mathrm{m}^{2}$, wanita usia 35-50 tahun, lingkar pinggang $>80 \mathrm{~cm}$, tidak mengonsumsi alkohol, tidak merokok, tidak mengonsumsi obat antihiperglikemi dan antihipertensi, tidak sedang hamil atau menyusui. Skrining tahap dua adalah memiliki Gula Darah Puasa (GDP) antara 100-125 mg/dl yang diukur dengan metode enzimatis Glucose Oxidase Phenol 4Aminophenazone (GODPAP) yang diukur oleh analis laboratorium Sarana Medika Semarang. bersedia menaati prosedur penelitian, dan menandatangani informed consent (IC). Berdasarkan 2 tahap skrining tersebut didapatkan 31 subjek. Sebanyak 3 orang dropout karena data tidak lengkap sehingga sampel yang digunakan adalah 28 orang.

Variabel bebas dalam penelitian ini adalah aktivitas fisik dan stress. Data aktivitas fisik diperoleh melalui wawancara menggunakan International Physical Activity Questionnaire (IPAQ), kemudian dihitung nilai MET-menit/minggu. Aktivitas fisik dikategorikan tidak aktif apabila $<600$ METmenit/minggu, aktif minimal apabila antara 600-3000 MET, dan sangat aktif apabila >3000 METmenit/minggu. Data stress diperoleh melalui wawancara menggunakan Perceived Stress Scale-10 (PSS-10), dimana hasilnya dikonversikan dalam bentuk angka kemudian dihitung nilai totalnya. Termasuk stress ringan apabila skor antara 1-13, stress sedang apabila skor antara 14-26, dan stress berat apabila skor antara 27-40. ${ }^{22-25}$ Variabel terikatnya adalah tekanan darah sistolik dan diastolic yang diukur menggunakan tensimeter digital Merek Omron HEM8712 dengan ketelitian $1 \mathrm{mmHg}$ yang diukur oleh enumerator pada pagi hari pukul $6.00-8.00$ WIB.
Variabel perancu adalah asupan lemak, sodium, kalsium, kalium, magnesium, dan serat. Data asupan diperoleh melalui wawancara dengan metode Recall 24jam selama 3 hari tidak berturut-turut dalam bentuk Ukuran Rumah Tangga (URT), kemudian dikonversi kedalam gram dan dihitung nilai gizinya menggunakan program komputer.

Data yang diperoleh kemudian diolah dan dianalisis secara statistik menggunakan program komputer. Data-data tersebut diuji normalitasnya menggunakan uji Shapiro-wilk karena jumlah sampel $<50$. Analisis univariat digunakan untuk mengetahui karakteristik subjek penelitian dan mendeskripsikan setiap variabel yang diteliti. Data yang bersifat kategorik disajikan dalam bentuk persentase, sedangkan data yang bersifat numerik disajikan dalam bentuk rerata (mean), standar deviasi, nilai minimum dan nilai maksimum dari setiap variabel.

Analisis bivariat dilakukan untuk melihat hubungan antara variabel bebas dengan variabel terikat. Uji statistik yang digunakan adalah uji korelasi uji korelasi rank Spearman karena data variabel terikat berdistribusi tidak normal. Pada penelitian ini analisi multivariat tidak dilakukan karena variabel perancu tidak signifikan secara statistik.

\section{HASIL}

\section{Karakteristik Subjek}

Subjek yang memenuhi kriteria inklusi pada penelitian ini berjumlah 28 orang yang didapatkan melalui skrining di Sendangmulyo dan Tandang (Kecamatan Tembalang) serta kantor pemerintah Kota Semarang di Gedung Pandanaran. Usia subjek berkisar antara 35-50 tahun dengan usia termuda adalah 35 tahun dan usia paling tua adalah 49 tahun. Rata-rata

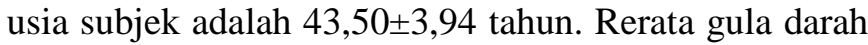
puasa sampel adalah 110,61 $\pm 11,18 \mathrm{mg} / \mathrm{dl}$. Dari 28 subjek, 21 diantaranya masuk dalam kategori hipertensi. Karakteristik subjek penelitian terdapat pada Tabel 1.

Tabel 1 menunjukkan bahwa berdasarkan uji normalitas menggunakan Saphiro-Wilk variabel tekanan aktivitas fisik dan stress berdistribusi normal $(p>0,05)$ sedangkan tekanan darah sistolik dan diastolik berdistribusi tidak normal. Mayoritas subjek (75\%) mengalami hipertensi. Tekanan darah sistolik berkisar antara 78-209 mmHg dengan nilai tengah $123 \mathrm{mmHg}$. Tekanan darah diastolik berkisar antara 67-121 mmHg dengan nilai tengah $86 \mathrm{mmHg}$. Subjek yang mempunyai tekanan darah sistolik $>130 \mathrm{mmHg}$ semuanya memiliki tekanan darah diastolik $>80 \mathrm{mmHg}$, tetapi terdapat subjek dengan tekanan sistolik normal meskipun tekanan darah diastoliknya tinggi. 
Tabel 1. Karakteristik Subjek Penelitian

\begin{tabular}{lcccc}
\hline \multicolumn{1}{c}{ Karakteristik } & n & $\%$ & Median & Mean \pm SD \\
\hline Tekanan Darah & & & $123 / 86$ & $125,93 \pm 24,25 / 89,25$ \\
Hipertensi $(\geq 130 / 80 \mathrm{mmHg})$ & 21 & 75 & & $\pm 14,64$ \\
Tidak Hipertensi $(<130 / 80 \mathrm{mmHg})$ & 7 & 25 & & $2.258,4 \pm 1.228,8$ \\
Aktivitas Fisik (MET-menit/minggu) & & & $2.152,5(132-4920)$ & \\
Tidak aktif (<600) & 3 & 10,7 & & $14,54 \pm 5,96$ \\
Aktif minimal (600-3000) & 18 & 64,3 & & \\
Sangat aktif (>3000) & 7 & 25 & & \\
Stress (skor) & 12 & 42,9 & & \\
Ringan (0-13) & 15 & 53,6 & & \\
Sedang (14-26) & 1 & 3,6 & & \\
Berat (27-40) & &
\end{tabular}

Aktivitas fisik subjek berkisar antara 132-4.920 MET-menit/minggu dengan rerata 2.258,4 $\pm 1.228,8$ MET-menit/minggu. Secara keseluruhan, 64,3\% subjek dikategorikan aktif minimal. Jenis aktivitas yang dilakukan subjek kebanyakan adalah aktivitas ringan dalam kehidupan sehari-hari, misalnya memasak, menyapu, mengepel, mencuci, dan menyetrika. Kegiatan tersebut pun dibantu oleh alat elektronik sehingga energi yang dibutuhkan lebih ringan. Aktivitas jalan yang dilakukan juga ringan, yaitu di sekitar rumah saja. Subjek dengan kategori sangat aktif (25\%) memiliki kebiasaan berolahraga 2-4 kali seminggu. Jenis olahraga yang dilakukan adalah renang, jogging, senam aerobik, dan bersepeda.
Tabel 2. Distribusi Kejadian Hipertensi berdasarkan Tingkat Aktivitas Fisik dan Stress.

\begin{tabular}{lcccc}
\hline \multirow{2}{*}{ Kategori } & \multicolumn{2}{c}{ Hipertensi } & \multicolumn{2}{c}{ Normotensi } \\
& n & \% & N & \% \\
\hline Aktivitas Fisik & & & & \\
Tidak aktif & 2 & 66,7 & 1 & 33,3 \\
Aktif minimal & 11 & 61,1 & 7 & 38,9 \\
$\quad$ Sangat aktif & 7 & 100 & - & - \\
\hline Stress & & & & \\
Ringan & 10 & 83,3 & 2 & 16,7 \\
Sedang & 10 & 66,7 & 5 & 33,3 \\
Berat & 1 & 100 & - & - \\
\hline
\end{tabular}

Tabel 3. Gambaran Asupan Subjek.

\begin{tabular}{|c|c|c|c|c|c|c|}
\hline Variabel & $\mathbf{n}$ & $\%$ & Median & Minimal & Maksimal & Mean \pm SD \\
\hline Asupan Lemak & & & 39,6 & 13,53 & 134,30 & $47,03 \pm 23,69$ \\
\hline Kurang $(<80 \%)$ & 15 & 53,6 & & & & \\
\hline Cukup (80-100\%) & 5 & 17,9 & & & & \\
\hline Lebih $(>100 \%)$ & 8 & 28,6 & & & & \\
\hline Asupan Serat (gr) & & & 6,5 & 2,50 & 26,87 & $8,28 \pm 5,41$ \\
\hline Kurang $(<80 \%)$ & 28 & 100 & & & & \\
\hline Cukup (80-100\%) & 0 & 0 & & & & \\
\hline Lebih $(>100 \%)$ & 0 & 0 & & & & \\
\hline Asupan Sodium (mg) & & & 172,61 & 41,13 & $1.003,90$ & $324,27 \pm 299,33$ \\
\hline Kurang $(<80 \%)$ & 28 & 100 & & & & \\
\hline Cukup (80-100\%) & - & - & & & & \\
\hline Lebih $(>100 \%)$ & - & - & & & & \\
\hline Asupan Kalium (mg) & & & $1.015,61$ & 361,50 & $2.896,30$ & $1.084,005 \pm 517,54$ \\
\hline Kurang $(<80 \%)$ & 28 & 100 & & & & \\
\hline Cukup (80-100\%) & - & - & & & & \\
\hline Lebih $(>100 \%)$ & - & - & & & & \\
\hline Asupan Kalsium (mg) & & & 193,53 & 14,54 & 461,37 & $208,75 \pm 116,71$ \\
\hline Kurang $(<80 \%)$ & 28 & 100 & & & & \\
\hline Cukup (80-100\%) & - & - & & & & \\
\hline Lebih $(>100 \%)$ & - & - & & & & \\
\hline Asupan Magnesium (mg) & & & 162,97 & 62,90 & 402,50 & $174,46 \pm 73,63$ \\
\hline Kurang $(<80 \%)$ & 26 & 92,9 & & & & \\
\hline Cukup (80-100\%) & - & - & & & & \\
\hline Lebih $(>100 \%)$ & 2 & 7,1 & & & & \\
\hline
\end{tabular}


Sebagian subjek $(53,6 \%)$ memiliki tingkat stress sedang. Tingkat stress berkisar pada skor antara 4-31 dengan rerata $14,54 \pm 5,96$. Terdapat 1 subjek yang dikategorikan stress berat dengan skor 31 . Hal tersebut dikarenakan subjek tersebut memiliki berbagai masalah dalam keluarga dan kesulitan untuk melakukan strategi guna menghadapi stress tersebut (coping). Subjek yang mengalami hipertensi mayoritas dikategorikan memiliki tingkat aktivitas fisik aktif minimal $(61,1 \%)$ dan subjek yang mengalami stress cenderung memiliki tekanan darah yang tinggi. Distribusi kejadian hipertensi berdasarkan aktivitas fisik dan stress dapat dilihat pada Tabel 2.

\section{Asupan Subjek}

Asupan yang diteliti dalam penelitian ini adalah asupan lemak, serat, sodium, kalium, kalsium, dan magnesium. Berikut adalah gambaran asupan subjek.

Tabel 3 menunjukkan sebagian besar subjek memiliki asupan lemak yang kurang, yaitu 15 orang $(53,6 \%)$. Sumber lemak yang sering dikonsumsi adalah gorengan, bakso, lauk yang diolah dengan digoreng. Semua subjek memiliki asupan serat, sodium, kalium, dan kalsium kurang. Sebanyak 92,9\% subjek memiliki asupan magnesium yang kurang, sedangkan 2 subjek asupan magnesiumnya berlebih.

Tabel 4. Hubungan Antara Aktivitas Fisik dan Stress dengan Tekanan Darah.

\begin{tabular}{lcccc}
\hline \multirow{2}{*}{ Variabel } & \multicolumn{2}{c}{ Tekanan Darah Sistolik } & \multicolumn{2}{c}{ Tekanan Darah Diastolik } \\
\cline { 2 - 5 } & Koefisien korelasi (r) & $\boldsymbol{p}$ value & Koefisien korelasi (r) & $\boldsymbol{p}$ value \\
\hline Aktivitas Fisik & 0,114 & 0,564 & 0,333 & $0,083^{*}$ \\
Stress & $-0,102$ & 0,604 & $-0,286$ & 0,14 \\
\hline
\end{tabular}

*Signifikan $(p<0,05)$

Hubungan Antara Aktivitas Fisik dan Stress dengan Tekanan Darah

Tabel 4 menunjukkan bahwa aktivitas fisik tidak memiliki hubungan yang bermakna dengan tekanan sistolik ( $\mathrm{r}=-0,114 ; p=0,564)$, tetapi memiliki hubungan yang bermakna dengan tekanan darah diastolik $(\mathrm{r}=0,333 ; p=0,083)$, sedangkan tingkat stress tidak memiliki hubungan yang bermakna dengan tekanan darah, baik sistolik maupun diastolik ( $\mathrm{r}=-0,102$, $p=0,604 ; \mathrm{r}=-0,286, p=0,14)$. Kekuatan hubungan antara aktivitas fisik dengan tekanan darah diastolik adalah sedang, dengan arah hubungan positif sehingga semakin tinggi aktivitas fisik maka tekanan darah diastolik akan semakin tinggi. Uji hubungan variabel perancu pada penelitian ini seperti tingkat kecukupan asupan lemak, serat, sodium, kalium, kalsium, dan magnesium dengan tekanan darah baik sistolik maupun diastolik menunjukkan tidak terdapat hubungan yang bermakna $(p>0,05)$ (tabel 5). Oleh karena itu tidak dilanjutkan untuk uji multivariat.

Tabel 5. Hubungan Antara Tingkat Kecukupan Asupan Lemak, Serat, Sodium, Kalium, Kalsium, dan Magnesium dengan Tekanan Darah.

\begin{tabular}{lcccc}
\hline \multirow{2}{*}{ Variabel } & \multicolumn{2}{c}{ Tekanan Darah Sistolik } & \multicolumn{2}{c}{ Tekanan Darah Diastolik } \\
\cline { 2 - 5 } & Koefisien korelasi (r) & $\boldsymbol{p}$ value & Koefisien korelasi (r) & $\boldsymbol{p}$ value \\
\hline Tingkat Asupan & & & & \\
Lemak & 0,124 & 0,529 & $-0,267$ & 0,170 \\
Serat & 0,175 & 0,374 & 0,142 & 0,471 \\
Sodium & $-0,178$ & 0,365 & $-0,213$ & 0,278 \\
Kalium & 0,214 & 0,218 & $-0,066$ & 0,783 \\
Kalsium & 0,241 & 0,218 & $-0,035$ & 0,859 \\
Magnesium & 0,05 & 0,802 & $-0,148$ & 0,454 \\
\hline
\end{tabular}

\section{PEMBAHASAN}

\section{Karakteristik Subjek}

Mayoritas subjek dalam penelitian $(75 \%)$ ini mengalami hipertensi. Ini menunjukkan bahwa hipertensi lebih sering ditemukan bersamaan dengan prediabetes dibandingkan terjadi secara tunggal. ${ }^{13} \mathrm{Hal}$ tersebut sejalan dengan penelitian di China yang menunjukkan bahwa $78,8 \%$ penderita prediabetes mengalami prehipertensi atau hipertensi. ${ }^{26}$ Hasil penelitian ini juga sejalan dengan penelitian Alicia dkk yang menunjukkan bahwa prevalensi hipertensi pada wanita prediabetes lebih tinggi dibanding nonhipertensi $(61,6 \%){ }^{27}$ Sebanyak 21 subjek yang mengalami hipertensi diketahui bahwa $57 \%$ dikategorikan aktif minimal dan $47 \%$ mengalami stress sedang.

Tingkat aktivitas subjek mayoritas adalah aktif minimal $(64,3 \%)$. Rerata aktivitas fisik dalam penelitian ini adalah 2.258,4 $\pm 1.228,8$ MET-menit/minggu. Jenis aktivitas yang lebih sering dilakukan adalah aktivitas ringan, misalnya berjalan lambat sekitar rumah, memasak, menyetrika, dll. Hal tersebut menunjukkan bahwa sebagian besar subjek memiliki aktivitas yang lebih rendah dibandingkan dengan rekomendasi 
menurut Diabetes Prevention Program (DPP). DPP merekomendasikan penderita prediabetes untuk melakukan aktivitas fisik minimal $700 \mathrm{kkal} /$ minggu atau setara dengan melakukan aktivitas sedang 150 menit/minggu. Contoh aktivitas sedang yang mudah dan paling banyak dilakukan adalah berjalan cepat. Aktivitas lain yang bisa dilakukan antara lain adalah senam aerobik, bersepeda, jogging, karate, berenang, tenis, dan voli. ${ }^{28}$

Tingkat stress yang dialami subjek dalam penelitian ini mayoritas adalah sedang $(53,6 \%)$, ringan $(42,8 \%)$ dan hanya $3 \%$ yang memiliki stress berat . Hasil tersebut sejalan dengan penelitian Muhsinin dan Laksono yang menyebutkan bahwa penderita hipertensi kebanyakan memiliki tingkat stress sedang. ${ }^{29}$ Subjek yang dikategorikan mengalami stress sedang 66,7\% diantaranya mengalami hipertensi.

Stress yang timbul pada penderita hipertensi merupakan hal yang wajar, baik itu disebabkan karena adanya perubahan mendadak pada aktivitas yang biasanya pasien lakukan maupun ketidakmampuan menyesuaikan diri dengan keadaan penyakit. Adanya pengobatan dan perubahan perilaku baik secara fisik maupun emosional juga menjadi stressor bagi pasien hipertensi. ${ }^{29}$

\section{Hubungan antara Aktivitas Fisik dengan Tekanan Darah}

Aktivitas fisik didefinisikan sebagai pergerakan tubuh yang dihasilkan oleh kontraksi otot rangka dan dapat meningkatkan energi ekspenditur. Aktivitas fisik ini mencakup berbagai macam pergerakan tubuh, mulai olahraga yang dilombakan, olahraga, hobi, atau aktivitas sehari-hari dalam rumah tangga. Kebalikannya, fisik yang tidak aktif didefinisikan sebagai keadaan dimana tubuh hanya melakukan gerakan minimal dan energi ekspenditur rata-rata adalah pada keadaan basal. ${ }^{30}$

Berdasarkan uji korelasi menggunakan Rank Spearman diketahui bahwa pada penelitian ini aktivitas fisik tidak berhubungan bermakna dengan tekanan darah sistolik, tetapi berhubungan secara bermakna dengan tekanan darah diastolik $(p<0,05)$. Hal ini mungkin disebabkan karena sebagian besar subjek pada penelitian ini melakukan aktivitas yang seragam. Hasil penelitian ini sejalan dengan penelitian yang dilakukan oleh Ayu Rahadiyanti dkk yang menyebutkan bahwa aktivitas fisik tidak berhubungan dengan hipertensi. ${ }^{31}$ Berbeda dengan penelitian yang dilakukan oleh Sindhu yang menyebutkan bahwa aktivitas fisik berhubungan dengan tekanan darah sistolik maupun diastolik dan juga penelitian di Malaysia yang menunjukkan adanya hubungan antara aktivitas fisik dengan tekanan darah sistolik saja. ${ }^{32,33}$ Penelitian ini menunjukkan bahwa hubungan antara aktivitas fisik dan tekanan darah diastolik menunjukkan hubungan positif yang artinya makin tinggi aktivitas fisik, makin tinggi tekanan darah diastolik.

Secara teoritis, aktivitas fisik berpengaruh terhadap tekanan darah. Semakin tinggi aktivitas fisik maka semakin kecil risiko terkena penyakit hipertensi. Seseorang dengan aktivitas ringan memiliki kecenderungan sekitar 30-50\% terkena hipertensi dibanding seseorang dengan aktivitas sedang atau berat. Aktivitas fisik yang dilakukan secara teratur dengan durasi yang tepat dapat menurunkan tekanan darah. Aktivitas fisik yang cukup dapat menguatkan jantung sehingga dapat memompa darah lebih baik tanpa harus mengeluarkan energi yang besar. Semakin ringan kerja jantung maka semakin sedikit tekanan darah pembuluh darah arteri sehingga mengakibatkan tekanan darah menurun. ${ }^{34}$ Aktivitas fisik yang dapat menurunkan tekanan darah tergantung pada jenis aktivitas, durasi, dan frekuensinya. Aktivitas fisik yang dianjurkan bagi penderita prediabetes adalah melakukan aktivitas fisik sedang pada kebanyakan hari dengan total minimal 150 menit/minggu. Jenis aktivitas yang disarankan antara lain adalah jalan cepat, senam aerobik, bersepeda, jogging, tenis, dan berenang. ${ }^{28}$

Penelitian ini menunjukkan bahwa aktivitas fisik memiliki hubungan yang bermakna dengan tekanan darah diastolik, tetapi tidak dengan tekanan darah sistolik. Hal tersebut dapat dikarenakan karena adanya perbedaan pengklasifikasian hipertensi. Pada penelitian ini subjek dianggap mengalami hipertensi apabila memiliki tekanan darah $\geq 130 / 80 \mathrm{mmHg}$ karena pada penderita prediabetes risiko terkena penyakit kardiovaskuler lebih tinggi dibanding orang tanpa prediabetes. ${ }^{10,11}$ Seseorang tanpa prediabetes baru dikatakan mengalami hipertensi apabila memiliki tekanan darah $\geq 140 / 90$ mmHg. ${ }^{9}$

Selain itu dapat disebabkan karena adanya bias ketika pengambilan data tingkat aktivitas fisik menggunakan IPAQ dan tingginya kecenderungan subjek untuk memberikan hasil yang baik sehingga menyebabkan terjadinya overestimate aktivitas fisik. Penelitian yang dilakukan oleh Lee dkk menyebutkan bahwa IPAQ cenderung memberikan hasil yang overestimate sebesar $84 \% .{ }^{33,35}$ Terjadinya overestimate terutama adalah pada aktivitas sehari-hari dan aktivitas yang berhubungan dengan berkebun. ${ }^{36}$

Pada penelitian ini aktivitas fisik hanya berhubungan bermakna dengan tekanan darah diastolik $(p<0,05)$. Hal tersebut dapat disebabkan karena $75 \%$ subjek memiliki tekanan darah diastolik $\geq 80 \mathrm{mmHg}$. Dari $75 \%$ subjek yang mengalami hipertensi, 52\% diantaranya mengalami hipertensi diastolik (tekanan darah diastolik tinggi, tetapi tekanan darah sistolik normal). Tekanan darah diastolik meningkat seiring bertambahnya usia, hingga usia mencapai 60 tahun.

Pada usia 35-50 tahun, secara biologis pembuluh darah masih berfungsi dengan baik, sehingga 
kemungkinan penyebab tingginya tekanan darah diastolik adalah karena terjadinya resistensi pembuluh darah perifer. Subjek dalam penelitian adalah ini adalah wanita prediabetes sehingga dimungkinkan kadar lipid dalam darah tinggi, menyebabkan naiknya kekentalan darah yang mengakiatkan naiknya resistensi pembuluh darah perifer dan tekanan darah diastolik. Rendahnya aktivitas fisik juga berpengaruh terhadap kenaikan tekanan darah. Selain itu, naiknya tekanan darah diastolik juga dipengaruhi oleh stress. Seseorang yang mengalami stress, baik stress karena pekerjaan maupun lingkungan, cenderung memiliki tekanan darah diastolik yang tinggi dibanding dengan seseorang yang tidak mengalami stress. ${ }^{37}$

\section{Hubungan antara Stress dengan Tekanan Darah}

Berdasarkan uji bivariat yang dilakukan, dalam penelitian ini stress tidak berhubungan secara signifikan dengan tekanan darah sistolik maupun diastolik $(p<0,05)$. Hal ini dapat disebabkan karena subjek mampu untuk mengatasi stress yang dialami sehingga tidak sampai berpengaruh terhadap kondisi fisiologis. Kondisi ini terlihat dari sebagian besar stress yang dialami responden masuk dalam kategori sedang dan ringan. Subjek dengan tingkat stress ringan dan sedang tidak menganggap besar masalah yang dialami, baik itu dari dalam diri subjek sendiri maupun dari lingkungan, dan dapat mengalihkan rasa stress tersebut dengan hal lain, misalnya dengan berekreasi, bermain bersama cucu, maupun berolahraga. Hasil penelitian ini berbeda dengan penelitian Katerin yang menunjukkan adanya hubungan yang bermakna antara stress dengan hipertensi. ${ }^{38}$

Stress adalah realita kehidupan yang tidak bisa dihindari. Stress atau ketegangan emosional dapat mempengaruhi sistem kardiovaskuler, khususnya hipertensi. Stress dipercaya dapat meningkatkan risiko hipertensi melalui aktivasi sistem saraf simpatis yang mengakibatkan naiknya tekanan darah secara intermiten (tidak menentu). Pada saat seseorang mengalami stres, hormon adrenalin akan dilepaskan dan kemudian akan meningkatkan tekanan darah melalui kontraksi arteri (vasokontriksi) dan peningkatan denyut jantung. Apabila stress berlanjut, tekanan darah akan tetap tinggi sehingga orang tersebut akan mengalami hipertensi. ${ }^{38}$

Kondisi stress meningkatkan aktivitas saraf simpatis yang kemudian meningkatkan tekanan darah secara bertahap, artinya semakin berat kondisi stres seseorang maka semakin tinggi pula tekanan darahnya. Stres merupakan rasa takut dan cemas dari perasaan dan tubuh seseorang terhadap adanya perubahan dari lingkungan. Apabila ada sesuatu hal yang mengancam secara fisiologis kelenjar pituitary otak akan mengirimkan hormon kelenjar endokrin kedalam darah. Hormon ini berfungsi untuk mengaktifkan hormon adrenalin dan hidrokosrtison, sehingga membuat tubuh dapat menyesuaikan diri terhadap perubahan yang terjadi. ${ }^{38}$

Secara alamiah dalam kondisi seperti ini seseorang akan merasakan detak jantung yang lebih cepat dan keringat dingin yang mengalir di daerah tengkuk. Selain itu peningkatan aliran darah ke otot-otot rangka dan penurunan aliran darah ke ginjal, kulit, dan saluran pencernaan juga dapat terjadi karena stres. Kondisi stres membuat tubuh menghasilkan hormon adrenalin lebih banyak, membuat jantung berkerja lebih kuat dan cepat. Apabila terjadi dalam jangka waktu yang lama maka akan timbul rangkaian reaksi dari organ tubuh lain. Perubahan fungsional tekanan darah yang disebabkan oleh kondisi stres dapat menyebabkan hipertropi kardiovaskuler bila berulang secara intermiten. Hal ini terlihat pada 1 subjek yang mengalami stress berat memiliki tekanan darah tinggi sampai 182/121 mmHg. Penderita hipertensi yang mengalami stress cenderung memiliki tekanan darah yang tetap tinggi atau bahkan semakin tinggi, sehingga menyebabkan kondisi hipertensinya makin buruk. ${ }^{38}$

\section{SIMPULAN}

Penelitian ini menunjukkan bahwa tidak terdapat hubungan yang signifikan antara aktivitas fisik dengan tekanan darah sistolik, tetapi terdapat hubungan yang signifikan antara aktivitas fisik dengan tekanan darah diastolik. Tidak terdapat hubungan yang signifikan antara tingkat stress dengan tekanan darah, baik sistolik maupun diastolik.

\section{SARAN}

Perlu dilakukan penelitian lebih lanjut dengan desain yang berbeda untuk melihat faktor risiko aktivitas fisik dan stress terhadap hipertensi.

\section{UCAPAN TERIMAKASIH}

Penelitian ini didanai melalui Hibah Penelitian dosen Fakultas Kedokteran Universitas Diponegoro tahun anggaran 2016.

\section{DAFTAR PUSTAKA}

1. Anjana RM, Pradeepa R, Deepa M, Datta M, Sudha V, Unnikrishnan R, et al. Prevalence of diabetes and prediabetes (impaired fasting glucose and/or impaired glucose tolerance) in urban and rural India: Phase I results of the Indian Council ofMedical Research-INdia DIABetes (ICMRINDIAB) study. Diabetologia. 2011;54:3022-7.

2. Soewondo P, Pramono LA. Prevalence, characteristics, and predictors of pre-diabetes in Indonesia. Med J Indones. 2011;2(4):283-94. 
3. Iloh GUP, Uchenna NR, Obiegbu NP. Risk factors of pre-diabetes among adult Nigerians with essential hypertension in a resource-constrained setting of a primary care clinic in eastern Nigeria. American Journal of Health Research. 2013;1(3):56-64.

4. III AGM, Tanner RJ, Baker R, Zayas CE, Harle CA. Prevalence of prediabetes in England from 2003 to 2011: population-based, cross-sectional study. BMJ Open. 2014;4:1-8.

5. Grahama E, Gariépy G, RachelJ.Burns, Schmitz N. Demographic, Lifestyle, and Health Characteristics Of Older Adults With Prediabetes In England. Elsevier. 2015;77:74-9.

6. Yan Q, Sun D, XuLi, Chen G, Zheng Q, Li L, et al. Association of Blood Glucose Level and Hypertension in Elderly Chinese Subjects: A Community Based Study. BMC Endocrine Disorders. 2016;16:40.

7. Balitbangkes. Riset Kesehatan Dasar 2007. In: RI DK, editor. Jakarta 2008.

8. Balitbangkes. Riset Kesehatan Dasar 2010. In: RI DK, editor. Jakarta 2010.

9. Pujol TJ, Tucker JE, Barnes JT. Disease of the Cardiovascuar System. In: Cossio Y, editor. Nutrition Therapy and Pathophysiology. 2 ed. USA: Wadsworth; 2011. p. 288.

10. Grossman E, Messerli FH. Management of Blood Pressure in Patients With Diabetes. American Journal of Hypertension. 2011;24(8):863.

11. Burgos-Lunar Cd, 'nez-Garci'a RJ, Salinero-Fort MA, Campelo PG, Gil A, Aba'nades-Herranz JC, et al. Trends in Hypertension Prevalence, Awareness, Treatment and Control in an Adult Type 2 Diabetes Spanish Population between 2003 and 2009. PLOS ONE. 2014;9(1):e86713.

12. Salanitro AH, Roumie CL. Blood Pressure Management in Patients With Diabetes. Clinical Diabetes. 2010;28(3):107.

13. Dhungana RR, Pandey AR, Bista B, Joshi S, Devkota S. Prevalence and Associated Factors of Hypertension: A Community-Based CrossSectional Study in Municipalities of Kathmandu, Nepal. International Journal of Hypertension. 2016;2016:7.

14. Nozoe S, Munemoto T. Stress and Hypertension. JMAJ,. 2002;45(5):187-91.

15. Schröder H, Schmelz E, J.Marrugat. Relationship between diet and blood pressure in a representative Mediterranean population. Eur J Nutr. 2002;41:161-7.

16. Bazzano LA. Dietary intake of fruit and vegetables and risk of diabetes mellitus and cardiovascular diseases. In: WHO, editor. Japan 2005.
17. Cheung BMY, Li C. Diabetes and Hypertension: Is There a Common Metabolic Pathway? Curr Atheroscler Rep. 2012;14:160-6.

18. Madhumitha.M, S N, Manohar.C. Influence of Stress and Socio Demographic Factors on Hypertension among Urban Adults in North Karnataka. Asian Journal of Biomedical and Pharmaceutical Sciences. 2014;4(38):23-6.

19. Mengesha AY. Hypertension and related risk factors in type 2 diabetes mellitus (DM) patients in Gaborone City Council (GCC) clinics, Gaborone, Botswana. African Health Sciences. 2007;7(1):244-5.

20. Hu B, Liu X, Yin S, Fan H, Feng F, Yuan J. Effects of Psychological Stress on Hypertension in Middle-Aged Chinese: A Cross-Sectional Study. PLoS ONE. 2015;10(6):9.

21. Winarto E, Yetti K, Mustikasari. Penurunan tekanan darah pada klien hipertensi primer melalui terapi hipnosis. Jurnal keperawatan Indonesia. 2011;14(1) : 65-72.

22. Maulana Z, Soleha T, Saftarina F, Siagian J. Differences in Stress Level Between First-Year and Second-YearMedical Students inMedical Faculty of Lampung University. ISSN.157.

23. Andreou E, Alexopoulos EC, Lionis C, Varvogli L, Gnardellis C, Chrousos GP, et al. Perceived Stress Scale: Reliability and Validity Study in Greece. Int J Environ Res Public Health. 2011;8:3287-98.

24. Pin TL. Hubungan Kebiasaan Berolahraga Dengan Tingkat Stres Pada Mahasiswa Fakultas Kedokteran Universitas Sumatera Utara Tahun Masuk 2008. Medan: Universitas Sumatra Utara; 2011.

25. Lee E-H. Review of the Psychometric Evidence of the Perceived Stress Scale. Asian Nursing Research. 2012;6:121-7.

26. Wu J, Yan W-h, Qiu L, Chen X-q, Guo X-z, Wu $\mathrm{W}$, et al. High Prevalence of coexisting prehypertension and prediabetes among healthy adults in Northern and Northeastern China. BMC Public Health. 2011;11:794-802.

27. Díaz-Redondo A, Giráldez-García C, Carrillo L, Serrano R, García-Soidán FJ, Artola $\mathrm{S}$, et al. Modifiable risk factors associated with prediabetes in men and women: a cross-sectional analysis of the cohort study in primary health care on the evolution of patients with prediabetes (PREDAPSStudy). BMC Family Practice. 2015;16:5.

28. The Diabetes Prevention Program's Lifestyle Change Program. 2000.

29. Muhlisin A, Laksono RA. Analisis Pengaruh Faktor Stres Terhadap Kekambuhan Penderita Hipertensi di Puskesmas Bendosari Sukoharjo. ISSN. 2011;2338-2694:42-8. 
30. Miles L. Physical Activity and Health. British Nutrition Foundation Nutrition Bulletin. 2007:314-63.

31. Rahadiyanti A, Setianto BY, Purba MB. Asupan makan DASH-like diet untuk mencegah risiko hipertensi pada wanita prediabetes. Jurnal Gizi Klinik Indonesia. 2015;11:115-25.

32. Mukt SN. Hubungan Aktivitas Fisik dan Asupan Energi Terhadap Tekanan Darah dan Kadar Glukosa Darah pada Mahasiswa Fakultas Kedokteran. Semarang: Undiversitas Diponegoro; 2014.

33. Teh CH, Chan YY, Lim KH, Kee CC, Lim KK, Yeo PS, et al. Association of physical activity with blood pressure and blood glucose among Malaysian adults: a population-based study. BMC Public Health. 2015;15:2-7.

34. Paruntu OL, Rumagit FA, Kures GS. Hubungan Aktivitas Fisik, Status Gizi Dan Hipertensi Pada Pegawai Di Wilayah Kecamatan Tomohon Utara. GIZIDO. 2015;7(1).

35. Lee PH, Macfarlane DJ, Lam T, Stewart SM. Validity of the international physical activity questionnaire short form (IPAQ-SF): A systematic review. International Journal of Behavioral Nutrition and Physical Activity. 2011;8(115).

36. Bermúdez VJ, Rojas JJ, Córdova EB, Añez R, Toledo A, Aguirre MA, et al. International Physical Activity Questionnaire Overestimation is Ameliorated by Individual Analysis of the Scores2013 [cited 201724 Sept]; 20(4):[448-58 pp.]. Available from: http://journals.lww.com/americantherapeutics/Abst ract/2013/07000/International_Physical_Activity_ Questionnaire.19.aspx.

37. Wang Y, Xing F, Liu R, Liu L, Zhu Y, Wen Y, et al. Isolated Diastolic Hypertension Associated Risk Factors among Chinese in Anhui Province, China. Int J Environ Res Public Health. 2015;12:4395405.

38. Islami KI. Hubungan Antara Stres Dengan Hipertensi Pada Pasien Rawat Jalan di Puskesmas Rapak Mahang Kabupaten Kutai Kartanegara Provinsi Kalimantan Timur. Surakarta: Universitas Muhammadiyah Surakarta; 2015. 